University of Rhode Island

DigitalCommons@URI

The Rhode Island Current Conditions Index

Economics

6-2004

\title{
Rhode Island Current Conditions Index -- June 2004
}

Leonard Lardaro

University of Rhode Island, lardaro@uri.edu

Follow this and additional works at: https://digitalcommons.uri.edu/ricci

Part of the Econometrics Commons

Terms of Use

All rights reserved under copyright.

\section{Recommended Citation}

Lardaro, Leonard, "Rhode Island Current Conditions Index -- June 2004" (2004). The Rhode Island Current Conditions Index. Paper 137.

https://digitalcommons.uri.edu/ricci/137

This Article is brought to you for free and open access by the Economics at DigitalCommons@URI. It has been accepted for inclusion in The Rhode Island Current Conditions Index by an authorized administrator of DigitalCommons@URI.For more information, please contact digitalcommons-group@uri.edu. 


\section{Current Conditions I ndex \\ LEONARD LARDARO URI}

Also available online: http:/ / members.cox.net/ lardaro/ current.htm

Volume X, Number 9

J une 2004

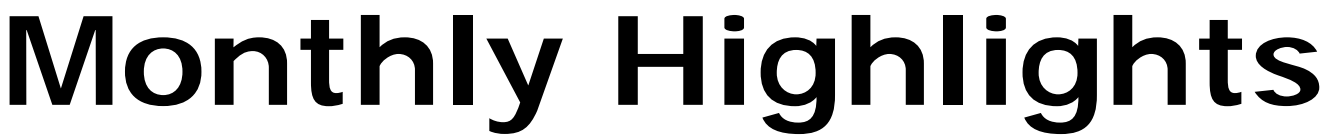

Just as the national economy hit a "soft patch" in June, so too did Rhode Island's economy. The second quarter ended on a sour note, as the June Current Conditions Index fell below its neutral value of 50. June's $\mathrm{CCl}$ reading of 42 was the result of only 5 of the $12 \mathrm{CCl}$ indicators improving. And, two of those, related to labor supply, registered significant weakness. Yet in spite of the recent "soft patch" experienced by the nation, national labor market performance was significantly better during the first half of this year than it was in Rhode Island. June payroll employment for Rhode Island was barely above its J anuary value (by only 600), a far cry from what the nation was witnessing. And our state's Unemployment Rate has now matched or exceeded the national rate for the last three months, after a long period with below-national-average values. Even more troubling was the joint behavior of our Labor Force and Unemployment Rate: Rhode Island 's Labor Force fell by 1.1 percent in June (compared to last June), while our Unemployment Rate rose from 5.4 percent to 5.8 percent. While a rising Unemployment Rate accompanied by a rising Labor Force is not necessary

\begin{tabular}{lr}
\multicolumn{2}{c}{ CCI Indicators - \% Change } \\
Government Employment & -0.1 \\
US Consumer Sentiment & $6.4 \mathbf{Y}$ \\
Single-Unit Permits & $13.0 \mathrm{Y}$ \\
Retail Sales & -0.9 \\
Help Wanted Advertising & 0.0 \\
Priv. Serv-Prod Employment & $0.7 \mathrm{Y}$ \\
Man-Hours Manufacturing & -0.6 \\
Manufacturing Wage & $1.5 \mathrm{Y}$ \\
Labor Force & -1.1 \\
Benefit Exhaustions & -12.9 Y \\
New Claims & 2.1 \\
Unemployment Rate & 7.4 \\
\multicolumn{1}{c}{ Y = I mproved Value } \\
\end{tabular}

problematic, as workers encouraged by economic conditions are generally re-entering the labor force, the combination witnessed here in June has no redeeming value. But is this at all surprising in light of Rhode Island's poor payrol employment performance in 2004?

Ironically, the best news about this month's performance concerns long-term unemployment, as measured by Benefit Exhaustions, which fell by 12.9 percent from its value last June. This was the third consecutive month with a double-digit improvement. New Claims, the most timely measure of layoffs, rose by 2.1 percent in June, its first increase in seven months. Private Service-Producing Employment continued to rise at a rate well below one percent. Along with this, Help Wanted Advertising remained unchanged in June, reflecting slowing labor demand. Private Service-Producing Employment growth continued to decelerate, with growth at only 0.6 percent in June, its slowest rate since February of 2002. And, in spite of ongoing budget difficulties, Government Employment fell very slightly in June, possibly the precursor of future budget-induced cutbacks.

The uneven pace of new home construction continued, as Single-Unit Permits surged by 13 percent in June, as the number of Permits climbed back over a 2,000 annual unit rate. The relatively small increases in our housing supply throughout this recovery suggest that current home price levels may well be sustainable in the future. Retail Sales fell slightly in June, only their second decline in the past six months. US Consumer Sentiment rose by 6.4 percent in June compared to the same month last year.

Rhode Island's manufacturing sector performance in June was mixed, as Manufacturing Man-hours fell by 0.6 percent, consistent with rates of decline over the past six months, and our Manufacturing Wage grew by 1.5 percent, part of an uptrend in growth rates which finally moved our Manufacturing Wage above $\$ 13$.

In the second half we face far more difficult "comps" (comparable year-earlier $\mathrm{CCl}$ values). While exceeding $\mathrm{CCl}$ values from the first half of 2003 was fairly easy, our slowed economy will make it very challenging to match many of the $\mathrm{CCl}$ values from the second half of 2003.

\section{Current Conditions I ndex}

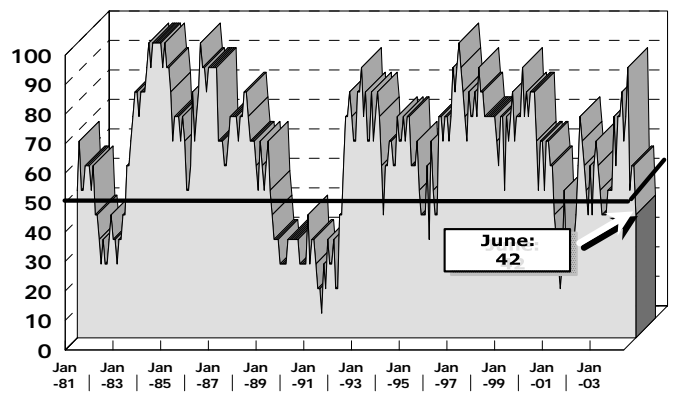

\begin{tabular}{|c|c|c|c|c|c|c|c|c|c|c|c|c|}
\hline & Jan & Feb & Mar & Apr & May & J un & $\mathbf{J} \mathbf{u l}$ & Aug & Sep & Oct & Nov & Dec \\
\hline 2003 & 42 & 42 & 42 & 50 & 50 & 50 & 75 & 58 & 75 & 75 & 83 & 67 \\
\hline 2004 & 75 & 92 & 50 & 58 & 58 & 42 & & & & & & \\
\hline
\end{tabular}

